\title{
Walnut somatic embryogenesis: physiological and histological aspects
}

\author{
D. Cornu
}

Amélioration des Arbres Forestiers, INRA Ardon, 45160 Olivet, France

\section{Introduction}

Somatic embryogenesis in plant tissue cultures has been reported for many species. For mass cloning, embryogenesis could be better than organogenesis because it directly produces full plants instead of shoots that have to be rooted. Thus, one major problem in plantlet production could be bypassed. Moreover, embryogenesis will be a better way to apply other techniques, such as protoplast fusion or gene transfer.

Recently, the induction of somatic embryogenesis has included more and more woody tree species, important conifers and hardwoods (for a recent review see Tulecke, 1987). For the Juglandacea family, somatic embryos have been obtained with Juglans regia, $J$. hindsii and Pterocarya (Tulecke and McGranahan, 1985), Carya illinoensis (Merkle et al., 1987), Juglans nigra, J. major and interspecific hybrids $J$. nigra $x$ $J$. regia (Cornu, 1988). As for many other hardwoods, all results were obtained with immature seeds and a lot of abnormal structures or embryos were frequently observed.
The aims of this work are: 1) to determine the developmental and physiological stages able to give rise to somatic embryogenesis; and, 2) to control histologically the true nature of somatic embryogenesis at an early stage.

\section{Materials and Methods}

The nuts were provided by Mr. Germain (INRA-Arboriculture, Bordeaux) from a half-sib family collected on black walnut (NG 23), which naturally produces a high level of hybrid nuts. Nuts (40 at each time) were collected from the end of June to early October at 2-3 week intervals. They were not cold stored and culture began not more than 5 days after collection.

For all experiments, we used media described by Tulecke and McGranahan (1985). For the conditioning step, we also used the medium defined by Gupta and Durzan (1986) for spruce. Cotyledon sections were prepared and cultivated as described previously (Cornu, 1988).

For histological studies, suitable tissue samples were fixed in a formaldehyde-acetic acid-ethanol mixture, dehydrated, embedded in paraffin, sectioned and finally stained with safranin or fast green. For very soft callus tissue, small pieces were directly stained with safranin and observed after squash preparation. 
Table I. Somatic embryogenesis from embryos or cotyledon tissue in relation to the development of nuts, after 4 weeks of culture on conditioning and induction media.

\begin{tabular}{|c|c|c|c|c|}
\hline \multirow{2}{*}{$\begin{array}{l}\text { Sample } \\
\text { date }\end{array}$} & \multicolumn{2}{|c|}{ Fruit development } & \multirow{2}{*}{$\begin{array}{l}\text { Endosperm } \\
\text { embryo + cotyledons }\end{array}$} & \multirow{2}{*}{$\begin{array}{l}\text { Reactivity } \\
\text { in culture }\end{array}$} \\
\hline & size $(\mathrm{mm})$ & shell & & \\
\hline $06 / 22$ & $\begin{array}{l}025 \\
\mathrm{~L} 35\end{array}$ & not lignified & $\begin{array}{l}\text { liquid endosperm } \\
\text { embryo } \leq 0.5 \mathrm{~mm}\end{array}$ & no growth and death \\
\hline $07 / 15$ & $\begin{array}{l}\oslash 35 \\
\text { L } 45\end{array}$ & $\begin{array}{l}\text { hardened } \\
\text { at tip }\end{array}$ & $\begin{array}{l}\text { liquid endosperm } \\
\text { embryo }+ \text { cotyl } \approx 1-3 \mathrm{~mm}\end{array}$ & soft callus necrosis \\
\hline $08 / 03$ & $\begin{array}{l}045 \\
\text { L } 60\end{array}$ & $\begin{array}{l}\text { more than half } \\
\text { lignified }\end{array}$ & $\begin{array}{l}\text { gelified endosperm } \\
\text { embryo } \approx 2 \times 5 \mathrm{~mm} \\
\text { cotyl. } \approx 15-25 \mathrm{~mm}\end{array}$ & $\begin{array}{l}\text { callus growth } \\
50 \% \text { of culture } \\
\Rightarrow \text { somatic embryos }\end{array}$ \\
\hline $09 / 01$ & $\begin{array}{l}045 \\
L 60\end{array}$ & $\begin{array}{l}\text { totally } \\
\text { lignified }\end{array}$ & $\begin{array}{l}\text { no endosperm } \\
\text { embryo } \approx 4 \times 7 \mathrm{~mm} \\
\text { cotyl. filled shell }\end{array}$ & $\begin{array}{l}\text { callus growth } \\
1 \text { callus gives } \\
\text { somatic embryos }\end{array}$ \\
\hline $10 / 05$ & $\begin{array}{l}\oslash 45 \\
L 60\end{array}$ & very hard & idem & $\begin{array}{l}\text { callus growth but } \\
\text { no organogenesis }\end{array}$ \\
\hline
\end{tabular}

$\varnothing=$ diameter, $L=$ length

\section{Results and Discussion}

For all collection times, we have obtained somatic embryogenesis only at the beginning of August and in one case in September (Table I) and only on the Tulecke arud McGranahan medium. This reactivity is connected with a particular stage of development of the nuts and occurs when the cotyledons show a high growth rate before they fill the locule. No cultures initiated from very early embryo stages, endosperms or mature embryos generated somatic embryos. This confirms the previous observations obtained on the reactivity of immature nuts of other walnut species (Tulecke and McGranahan, 1985; Cornu, 1988).

For Juglans regia the best stage for obtaining embryogenesis corresponds, in percentage of dry weight, to the highest content in protein and to the beginning of the decrease in soluble sugar and the increase in oil content (Labavitch and Polito, 1985). The interaction of the metabolic content of cotyledons and the culture medium could, in fact, play a major role in the induction or the development of induc- ible cells in somatic embryogenesis. Consequently, we cannot be certain that our culture conditions were optimal for generating somatic embryos for more samples. In terms of growth regulators, auxins (normally not necessary for walnut micropropagation) are needed for the early conditioning medium $(0.01 \mathrm{mg} / \mathrm{l}$ of indole butyric acid). This is in accordance with the results of Label and Cornu (1988), who found a particularly high concentration of indole acetic acid in the liquid endosperm at the corresponding stage of development.

During the first months of culture, the embryogenic lines gave compact white calluses similar to the original cotyledons. These calluses were embryogenic but in very limited areas. The adventive somatic embryos are frequently abnormal and do not complete their development to plantlets. Progressively, new calluses appear which are more irregular, soft, crumbly, moussey and which grow actively. In these calluses, we can distinguish different kinds of cells: 1) large elongated cells with a large vacuole; and, 2) small dense cells, like meristematic cells which gather to- 
gether in micro- or macro-calluses. The structure of the callus depends directly upon the ratio of these 2 types of cells. The dense calluses show a very high capacity for embryogenesis. They generate large clusters of embryos at different stages of development (from the globular to the torpedo and even early cotyledonary form). At this late stage, embryos could be isolated, but to date only $20 \%$ complete their in vitro development with root and shoot growth. This heterogeneous callus development is similar to that described for conifers (Becwar et al., 1988) except that elongated cells seem not to be active in the process of somatic embryogenesis (suspensor-like function). Finally, this kind of callus could be used to initiate agitated liquid cultures, which are easier to handle and more efficient for producing better and homogeneous somatic embryos.

\section{Conclusion}

We have obtained true somatic embryos in hybrid walnut. Our results indicate that there may be an optimal period of zygotic embryo development for the generation of somatic embryos. Not all zygotic embryos respond. Further investigations are needed to determine if an optimum physiological 'window' exists for initiating embryogenic cultures, or if other factors (particularly medium composition) limit the cell redetermination of more mature material. Analysis of liquid endosperm at all stages of development of the zygotic embryo could be worthwhile in such investigations.

\section{References}

Becwar M.R., Wann S.R., Johnson M.A., Verhagen S.A., Feirer R.P. \& Nagmani R. (1988) Development and characterization of in vitro embryogenic systems in conifers. In: Somatic Cell Genetics of Woody Plants. (Ahuja M.R., ed.), Kluwer Academic Publ., pp. 1-18

Cornu D. (1988) Somatic embryogenesis in tissue cultures of walnut (Juglans nigra, J. major and hybrids $J$. nigra $\times J$. regia). In: Somatic Cell Genetics of Woody Plants. (Ahuja M.R., ed.), Kluwer Academic Publ., pp. 45-49

Gupta P.K. \& Durzan D.J. (1986) Plantlet regeneration via somatic embryogenesis from subcultured callus of mature embryos of Picea abies (Norway spruce). In vitro 22, 685-688

Labavitch J.M. \& Polito V.S. (1985) Fruit growth and development. In: Walnut Orchard Management. University of California, Publ. no. 21410 pp. 90-94

Label P. \& Cornu D. (1988) Determination of plant growth substances in liquid endosperm of immature walnut (Juglans nigra) nuts by an ELISA technique. Plant Growth Regul. 7, 209215

Merkle S.A., Wetzstein H.Y. \& Sommer H.E. (1987) Somatic embryogenesis in tissue cultures of pecan. HortScience 22, 128-130

Tulecke W. (1987) Somatic embryogenesis in woody perennials. In: Cell and Tissue Culture in Forestry, Vol. 2 (Bonga J.M. \& Durzan D.J., eds.), Martinus Nijhoff Publ, Dordrecht, pp. 6191

Tulecke W. \& McGranahan G. (1985) Somatic embryogenesis and plant regeneration from cotyledons of wainut, Juglans regia. Plant Sci. $40,57-63$ 